\title{
Effect of Surface Morphology on Dimerization of tert-Butyl Mercaptan on the Surface of Amorphous Aluminosilicate Impregnated with $\mathrm{Mn}$ and $\mathrm{Cu}$
}

\author{
Jeong Eun Kweon, Hyunha Joo, and Dong Gon Park ${ }^{\star}$ \\ Department of Chemisty, Sookmyung Women's University, Seoul 140-742, Korea. "E-mail: dgpark@sookmynng.ackr. \\ Received Angust 9, 2005
}

\begin{abstract}
$\Lambda$ powder of destructive adsorbent was prepared by impregnating $\mathrm{Mn}$ and $\mathrm{Cu}$ on the surface of amorphous aluminosilicate. It catalytically dimerized tert-butyl mercaptan into di-tert-butyl disulfide on its surface. Turnover of the dimerization was strongly dependent on the surface morphology of the adsorbent, which could be altered by modification of aluminosilicate support. During the process of impregnation, which involved heat-treatment at $500{ }^{\circ} \mathrm{C}$, the shape of the pore was preserved, though large fraction of micropores were eliminated. The reactive sites on the surface were poisoned as dimerization products strongly adhered on them. Therefore, high surface area was not always desirable. When the surface was heavily populated with "inkbottled" pores with a narrow entrance in uniform size, heavy poisoning of the reactive sites turned the destructive adsorbents almost useless.
\end{abstract}

Key Words : Aluminosilicate, tert-Butyl mercaptan, Dimerization, Porosimetry

\section{Introduction}

As the living standard improves, there has been much concern on comfortable living environment. As living space tends to adopt more closed setting than in the past, much demand and research effort has been created to put "malodor" under control. ${ }^{1-3}$ Common sources of the bad smell around living space are foods. The smell from the foods gets especially unpleasant when they become overfermented or rotten. In a few far-eastern countries, such as Korea and Japan, variety of fermented foods are daily consumed, which contain both fish or garlic. When overfermented or rotten, these foods tend to produce various malodorant volatile compounds. Most of these malodorant compounds fall into two categories, mercaptan and amine derivatives. ${ }^{4.5}$

Even very small amount of mercantan compounds gives very strong unpleasant sensation to human olfactory nerves. We deal with those malodorant compounds everyday, without knowing they consist of mercaptan compounds. As an example, methyl mercaptan $\left(\mathrm{CH}_{3} \mathrm{SH}\right)$ is a major gas compound generated from over-fermented Kimchi products. It is very pervasive compound that it ruins plastic containers, woven products, even tastes of all other nearby foods including water and ice. tert-Butyl mercaptan, TBM $\left(\mathrm{C}_{4} \mathrm{H}_{9} \mathrm{SH}\right)$, also has very strong unpleasant stench. As a safety measure, TBM has intentionally been added into a flammable gas, such as liquefied natural or propane gasses (LNG or LPG). ${ }^{6}$ Mixing process for TBM into liquefied gases often accompanies very small amount of a leak, which triggers a false alarm.

The most common measure to control malodorant volatile compounds is to use adsorbents, porous solids with high surface area, such as activated carbons or zeolites. They utilize simple physisorption as a means to get rid of the malodorant volatile compounds. Commercial deodorizing products in the market nowadays are mostly these adsorbents. Because the malodorants are removed only by physisorption, the lifetime of this kind is very limited. Malodorants can also be passified via oxidation by ozone.' But, a device for ozone generation is rather expensive, and it keeps consuming electric energy during the use. Moreover, mercaptans are resistant to oxidizing agents.

As an alternative way to get rid of stench from alkylmercaptan compounds without energy consumption, we previously suggested the use of destructive adsorbents, which are porous silica impregnated with transition metals, active to the catalytic dimerization of mercaptans. ${ }^{7}$ On the surface of the destructive adsorbents, alkyl mercaptan was dimerized into dialkyl disulfide, and its malodor was passified. It was shown that oxygen in the atmosphere is closely involved in the dimerization reaction, possibly through scrambling with the lattice oxygen on the surface of the oxides. ${ }^{8}$ Even though reaction mechanism is partly understood, influence by other factors, such as composition of the adsorbents, defects on the surface, porosity, and especially the surface morphology of the adsorbents, still remain unknown. In order to verify such influences, one should first get an appropriate means to prepare comparison samples. We report preparation of two different comparison samples of the destructive adsorbents by modifying surface morphology of amorphous aluminosilicate supports through manipulation of precipitation process.

\section{Experimental Section}

Aqueous solution of silicate was prepared by dissolving $12.2 \mathrm{~g}$ of $\mathrm{Na}_{2} \mathrm{SiO}_{3}$ (reagent grade, Junsei Chemical) in 12 $\mathrm{mL}$ distilled water. In a separate container, aqueous solution of aluminate was prepared by dissolving $8.2 \mathrm{~g}$ of $\mathrm{NaAlO}_{2}$ (reagent grade, Junsei Chemical) in $60 \mathrm{~mL}$ distilled water. Mole ratio of $\mathrm{Si}$ to $\mathrm{Al}$ was roughly one to one. The aluminate 
solution was dropwise added into the silicate solution, which turned the mixture into a thick colloidal solution. The coagulated colloidal solution was peptized into aluminosilicate sol by adding $60 \mathrm{~mL}$. of $6 \mathrm{~N} \mathrm{HCl}$ solution during several hours. Then, coprecipitation into aluminosilicate hydrogel was carried out by dropwise addition of $6 \mathrm{~N} \mathrm{NaOH}$ into the aluminosilicate sol. During all the mixing processes, the mixture was vigrorously agitated using a mechanical stirrer. The addition of the $\mathrm{NaOH}$ solution was terminated when basicity of the solution reached $\mathrm{pH}=7$, or $\mathrm{pH}=11$. The precipitate was collected by filtration. After salt was removed by thorough washing, the precipitate was dried overnignt in an oven at $120^{\circ} \mathrm{C}$, and was used as a support for the destructive adsorbent. For descriptive convenience, the amorphous aluminosilicate powders obtained at $\mathrm{pH}=7$ and $\mathrm{pH}=11$ will be designated as $\mathrm{Al}_{2} \mathrm{Si}_{2} \mathrm{O}_{7}\left(\mathrm{pH}\right.$ 7) and $\mathrm{Al}_{2} \mathrm{Si}_{2} \mathrm{O}_{7}(\mathrm{pH} \mathrm{11)}$, respectively.

About $2 \mathrm{~g}$ of the aluminosilicate support was weighed and dispersed in $100 \mathrm{~mL}$ distilled water. In a separate container, $\mathrm{Mn}\left(\mathrm{NO}_{3}\right)_{2} \cdot 4 \mathrm{H}_{2} \mathrm{O}$ and $\mathrm{Cu}\left(\mathrm{NO}_{3}\right)_{2} \cdot 3 \mathrm{H}_{2} \mathrm{O}$ (both reagent grade, Deoksan Chemical) were dissolved in a minimal amount of water, and added over the aluminosilicate. The amounts of the metal constituents were adjusted to 8 and $4 \%$ to the weight of the aluminosilicate support, for $\mathrm{Mn}$ and $\mathrm{Cu}$, respectively. In a water bath at around $80^{\circ} \mathrm{C}$, the mixture was turned into a wet paste by slowly removing water from it. After overnight drying in an oven at $120^{\circ} \mathrm{C}$, the dark brown solid was further ground into a fine powder. By heating at $500{ }^{\circ} \mathrm{C}$ for $12 \mathrm{~h}$ under nitrogen atmosphere, the brown powder was turned into the destruetive adsorbent, aluminosilicate impregnated with $\mathrm{Mn}$ and $\mathrm{Cu}$, which will be designated as '[ $\mathrm{Mn} / \mathrm{Cu}] \mathrm{Al}_{2} \mathrm{Si}_{2} \mathrm{O}_{7}$ '.

Nitrogen isotherms were measured by Micromeritics ASAP 2400. Surface area was calculated by ВГ:T method."
Pore size distribution was calculated by B.JH method from the desorption curve of the nitrogen isotherm. ${ }^{10}$ Information on micropores in the powder sample was obtained by t-plot derived from the adsorption curve of the isotherm. ${ }^{9}$ FTIR spectra were in-situ measured by Nicolet Impact 400 spectrophotometer from head-gas over $0.1 \mathrm{~g}$ of [ $\mathrm{Mn}$ $\mathrm{Cu}] \mathrm{Al}_{2} \mathrm{Si}_{2} \mathrm{O}_{7}$ powder in a cylindrical gess cell $(50 \mathrm{mI}$. inner volume). TBM was injected as a pulse into the eell over the powder, so that the initial coneentration of TBM was 5 ppt. Immediately after injection, FTIR spectrum was taken every 3 min. Fight to ten measurements were made for each pulse. The gas product was also characterized by gas-chromatograph/mass-spectrometry (GC.-MS), using Finnigan Automass 300 . In a homemade reactor vessel $(100 \mathrm{~mL}$ inner volume), licjuid mereaptan was in-situ evaporated over $0.1 \mathrm{~g}$ $[\mathrm{Mn} / \mathrm{Cu}] \mathrm{Al}_{2} \mathrm{Si}_{2} \mathrm{O}_{7}$ powder, and GC/MS measurements were carried out on aliquots of the head-gas over the time. The initial coneentration of TBM in the reactor was adjusted to $100 \mathrm{ppt}$, which would render the amount of TBM to be $40-$ fold larger than in the previous FT-IR measurements.

\section{Results and Discussion}

Mechanism of particle growth in a silicate solution is well understood. " Solid particles in the solution tend to form an interwoven network strueture of silica hydrogel in the range of $\mathrm{pH} 7$ to 10, when salt is present in the solution of silicic acid. Without salt, inter-condensation of the particles is suppressed, and they tend to grow into large colloidal particles via Ostwald ripening. In higher $\mathrm{pH}$, ripening of the particles is also enhanced. Unlike in a single component system, the mechanism of particle growth is not much sludied for multi-component system, where hydroxides of more than two metals are involved. But, it is suggested that it
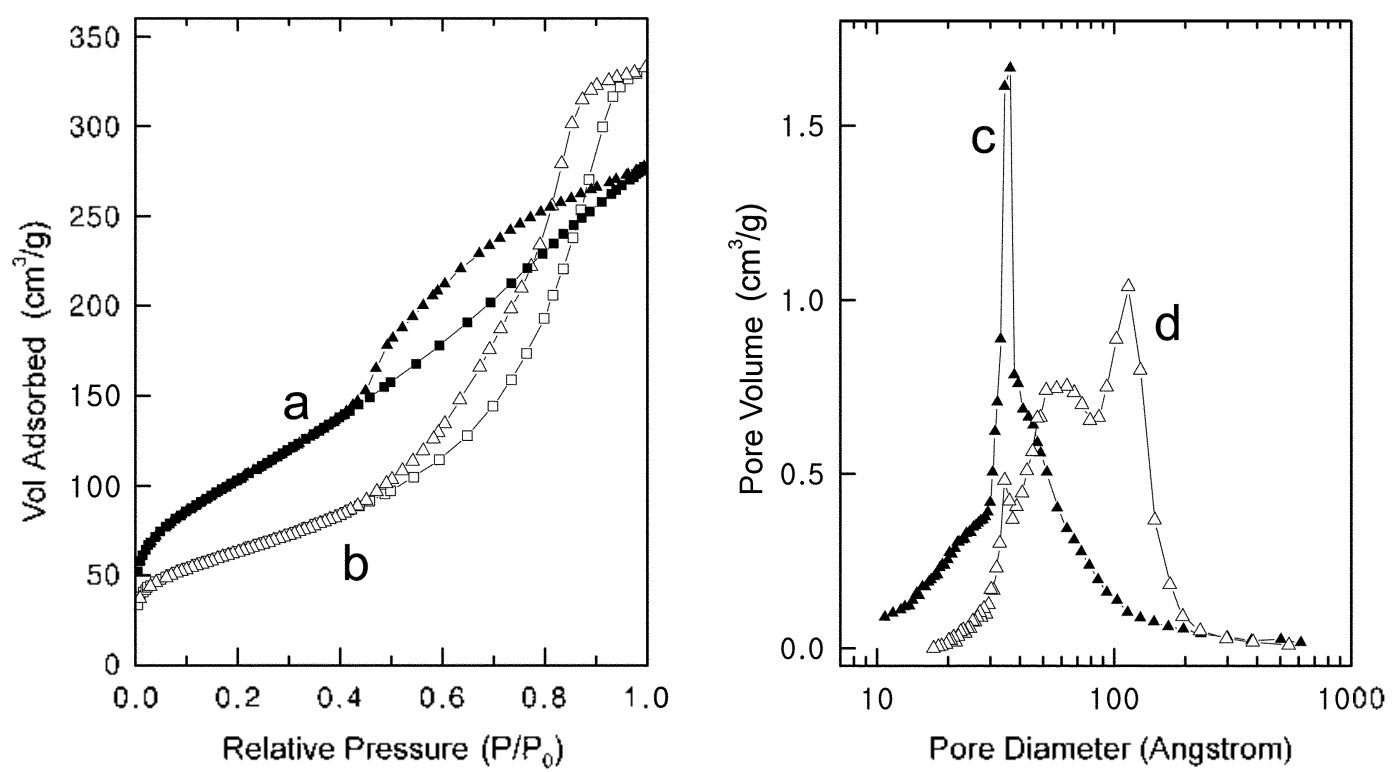

Figure 1. Isotherms of nitrogen adsorption-desorption measured for amorphous aluminosilicate supports, (a) on the surface of $\mathrm{Al}_{2} \mathrm{Si}_{2} \mathrm{O}_{7}(\mathrm{pH}$ 7), (b), and on the surface of $\mathrm{Al}_{2} \mathrm{Si}_{2} \mathrm{O}_{7}$ (pt l ] l). Pore size distributions, (c) for $\mathrm{Al}_{2} \mathrm{Si}_{2} \mathrm{O}_{7}$ (pll 7), and (d) for $\mathrm{Al}_{2} \mathrm{Si}_{2} \mathrm{O}_{7}$ (pl $1 \mathrm{ll}$ ). The distribution was calculated by BJI method from the desorption curve of the corresponding isotherm. 
would be similar to the one for the silicic acid.

When aqueous solutions of silicate and aluminate were mixed together, they immediately solidified into a mass that further manipulation was not possible. Slow dropwise addition with a vigorous agitation, and addition of aluminate over silicate solution, not the other way, was erucial to enet a colloidal solution of aluminosilicate. A portion of the solution was set aside in order to collect aluminosilicate particles in the solution by filtration. BFT surface area of the aluminosilicate particles at this stage was mere $7.8 \mathrm{~m}^{2} / \mathrm{g}$, and was too smatl for the use as a support.

Modification of the colloidal aluminosilicate was carried out via peptization followed by condensation. Peptization broke down the colloidal particles into much smaller ones. As dissolution of the partieles proceded, the white nontransparent solution turned into a elear one with some haziness, which indicated the size of the particles was below $100 \mathrm{~nm}$. The small particles were reassembled into bigger ones by condensation among them. The particle growth via condensation was initiated by addition of $\mathrm{NaOH}$ into the solution, which turned the solution turbid. After the treatment, amorphous aluminosilicate was obtained in morphology very different from the original colloidal solids.
The BFT surface area of the amorphous powders of aluminosilicates obtained after the modification inereased more than 30-fold (from 7.8 to 370 , and $230 \mathrm{~m}^{2} / \mathrm{g}$ in Table 1). In lower $\mathrm{pH}$, average pore diameter gets smaller, and BFT surface area gets larger. This observation indicates the surface morphology of the aluominosilicate was modified by $\mathrm{pH}$ of the solution during condensation among particles. Figure 1a and $1 \mathrm{~b}$ shows the isothems of nitrogen adsorption-desorption on those two different powder samples. They both exhibit hysteresis, which provides information on the structure of the pore. Type $\mathrm{H} 2$ hysteresis in Figure la indicates $\mathrm{Al}_{2} \mathrm{Si}_{2} \mathrm{O}_{7}(\mathrm{pH} 7)$ has pores with a unifom sized small entrance, like in parallel slits or so called "ink-bottled" pores. ${ }^{30}$ The size of the entrance has fairly narrow distribution around $35 \AA$, as assessed by the pore size distribution curve in Figure 1c. On the contrary, the isothern for $\mathrm{Al}_{2} \mathrm{Si}_{2} \mathrm{O}_{7}$ (pH 11) has type $\mathrm{Hl}$ hysteresis, in Figure $1 \mathrm{~b}$, indicating it has cylindrical pores. ${ }^{10}$ The size of the cylindrical pores is widely distributed from around 35 to $150 \AA$ as seen in Figure $1 \mathrm{~d}$.

They also contain mieropores, by secing that the infliction of the isothem is raised at lower end of the relative pressure. Microporous surface areas were ealeulated from the slopes

Table 1. Pore characteristics for the supports and destructive adsorbents

\begin{tabular}{|c|c|c|c|c|c|c|}
\hline Sample & $\mathrm{S}_{\mathrm{e}}$ & $\Delta \mathrm{S}_{\mathrm{t}}$ & $\mathrm{d}_{\mathrm{ater}}$ & $S_{\text {micro }}$ & $\Delta S_{\text {nicro }}$ & $S_{\text {metso-mikio }}$ \\
\hline Before modification & 7.8 & - & - & - & - & - \\
\hline $\mathrm{Al}_{2} \mathrm{Si}_{2} \mathrm{O}_{7}(\mathrm{pH} 7)$ & 370.2 & - & 46.4 & 324.5 & - & 45.7 \\
\hline $\mathrm{Al}_{2} \mathrm{Si}_{2} \mathrm{O}_{7}(\mathrm{pH} 11)$ & 229.6 & - & 89.6 & 184.0 & - & 45.6 \\
\hline$[\mathrm{Mn} / \mathrm{Cu}] \mathrm{Al}_{2} \mathrm{Si}_{2} \mathrm{O}_{7}(\mathrm{pH} 7)$ & 189.1 & 181.1 & 53.0 & 151.1 & 173.4 & 38.0 \\
\hline$\left[\mathrm{Mn} / \mathrm{Cu}^{\prime}\right] \mathrm{Al}_{2} \mathrm{Si}_{2} \mathrm{O}_{7}(\mathrm{pH}$ & 129.2 & 100.4 & 108.7 & 87.0 & 97.0 & 42.2 \\
\hline
\end{tabular}

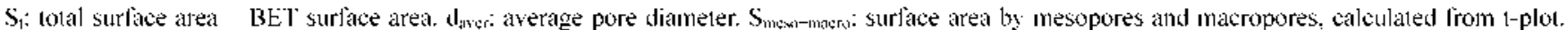
$S_{\text {micni }}$ surface area by micropores $=S_{1}-S_{\text {rutsu mitum }} \Delta$ : change after impregnation and heal-trealment.
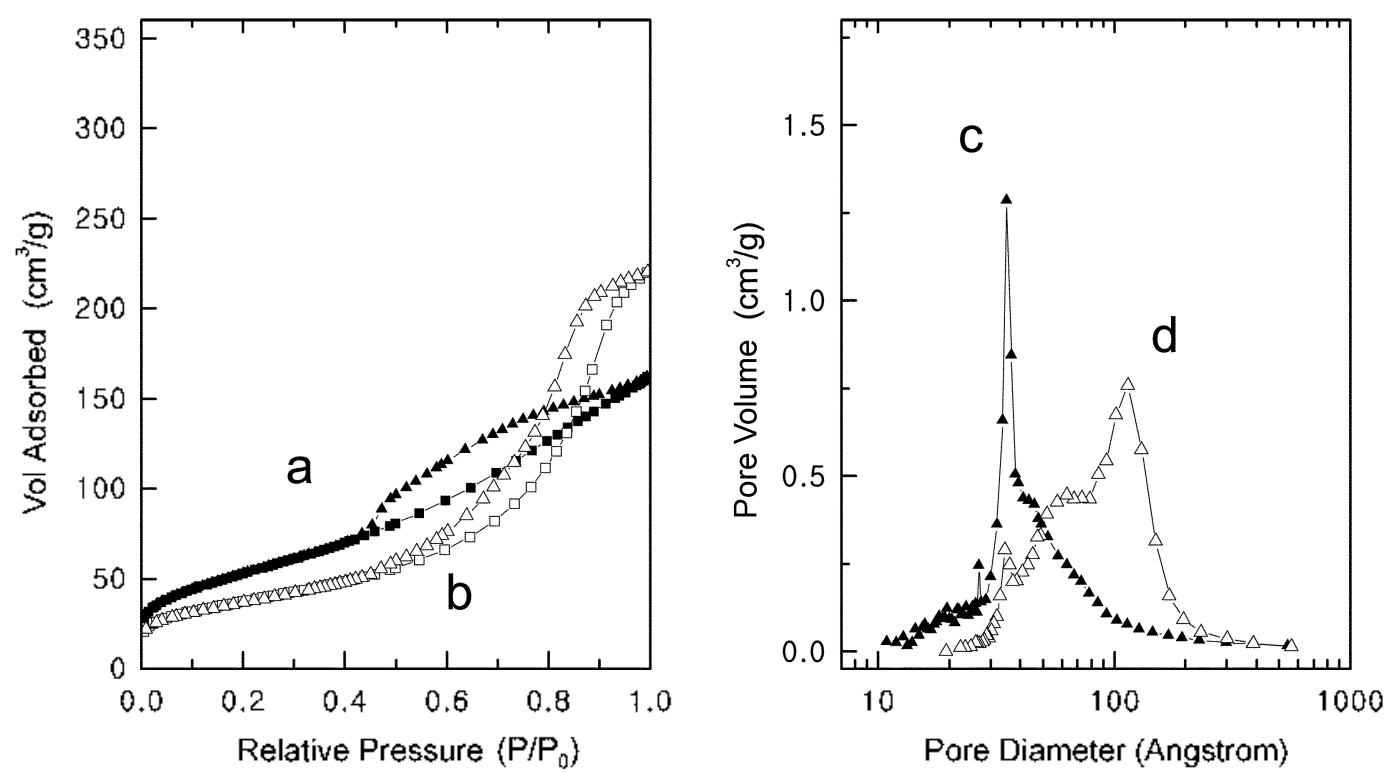

Figure 2. Jsotherms of nitrogen adsorption-desorption measured for destructive adsorbents, (a) on the surface of $|\mathrm{Mn} / \mathrm{Cu}| \mathrm{Al} 1_{2} \mathrm{Si} \mathrm{O}_{2} \mathrm{O}_{7}(\mathrm{pH} / 7)$, (b), and on the surface of $[\mathrm{Mn} / \mathrm{Cu}] \mathrm{Al}_{2} \mathrm{Si}_{2} \mathrm{O}_{7}(\mathrm{pH} \mathrm{Il})$. Pore size distributions, (c) for $[\mathrm{Mn} / \mathrm{Cu}] \mathrm{Al}_{2} \mathrm{Si}_{2} \mathrm{O}_{7}\left(\mathrm{pH} 7\right.$ ), and (d) for $[\mathrm{Mn} / \mathrm{Cu}] \mathrm{Al}_{2} \mathrm{Si}_{2} \mathrm{O}_{7}$ $(\mathrm{pH} 11)$. The distribution was calculated by $\mathrm{BJH}$ method from the desorption curve of the corresponding isotherm. 
of the l-plots derived from the isotherns," and are provided in Table 1. $\mathrm{In}_{1} \mathrm{Al}_{2} \mathrm{Si}_{2} \mathrm{O}_{7}(\mathrm{pH}$ 7), micropores contribute more to the total surface area than in $\mathrm{Al}_{2} \mathrm{Si}_{2} \mathrm{O}_{7}(\mathrm{pH} 11)$. This observation suggests the particle size was smaller at lower $\mathrm{pH}$, which conforms to the prediction based on the study on the silica sol. A study on the generation of silica particles from silicic acid suggests that the rate of condensation among particles competes with the speed of particle growth by Ostwald ripening, when the solution contains salt which can alleviate repulsion among negatively charged particles. " Because aluminosilicate solution contained plenty of salt, which came from $\mathrm{HCl}$ and $\mathrm{NaOH}$, highly branched interwoven network structure should result when $\mathrm{pH}$ was betow 10. As it gets more basic, the size of the particle shall increase, because particle growth will be enhanced, and network formation will be suppressed.

Once obtaining a leverage to control the pore morphology of the support, our next concern was whether it would be sustained through out the subsequent impregnation and heattreatment at $500^{\circ} \mathrm{C}$. It was shown, in our previous studies, that the heal-treatment during impregnation largely altered the shape of the pore, in silica acroget ${ }^{7}$ and magnesia acrogel.'2 The isothems of nitrogen adsorption-desorption were shown in Figure 2 for those desteructive adsorbents, $[\mathrm{Mn} / \mathrm{Cu}] \mathrm{Al}_{2} \mathrm{Si}_{2} \mathrm{O}_{7}(\mathrm{pH} 7)$ and $[\mathrm{Mn} / \mathrm{Cu}] \mathrm{Al}_{2} \mathrm{Si}_{2} \mathrm{O}_{7}(\mathrm{pH} 11)$. ВГT surface area, average pore diameter, and surface area from micropores are provided in Table 1. Considering that the shape of the hysteresis was preserved (compare figure $1 a-b$ with $2 a-b)$, the pore morphology of the aluminosilicale support was not much altered even after impregnation with nitrates of $\mathrm{Mn}$ and $\mathrm{Cu}$, followed by heating al $500^{\circ} \mathrm{C}$.
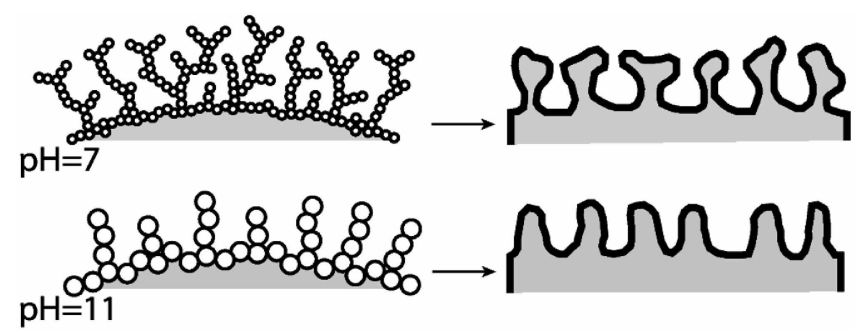

Figure 3. Hypothetical cross-sections of the destruclive adsorbents constructed on the basis of the observations by porosimelry. The surface of the samples prepared at pl $[-7$ has mesopores with narrower entrances, and has higher population of micropores, than those obtained at $\mathrm{pH}=11$.

Teven though it did not change the shape of the pore, leattreatment caused a significant decrease in ВГT surface area (see table 1). The extent of the decrease was especially large $\left(\Delta \mathrm{S}_{1}=181 \mathrm{~m}^{2} / \mathrm{g}\right)$ in $[\mathrm{Mn} / \mathrm{Cu}] \mathrm{Al}_{2} \mathrm{Si}_{2} \mathrm{O}_{7}(\mathrm{pH} 7)$. It is interesting to note that the extent of the decrease accompanied by impregnation is nearly identical for $\Delta S_{6}$ and $\Delta S_{\text {miicrem. It }}$ suggests that the loss of the surface area was mostly caused by elimination of the mieropores. The value of $S_{\text {miwson mare }}$ did not change much after the heat-treatment. This conforms to the observation that size distribution curves did not change much over the mesoporous range (compare figure $1 \mathrm{e}-\mathrm{b}$ with figure 2c-d). Based on these observations, hypothetical cross-sectional vicw of $[\mathrm{Mn} / \mathrm{Cu}] \mathrm{Al}_{2} \mathrm{Si}_{2} \mathrm{O}_{7}(\mathrm{pH}$ 7) was compared to that of $[\mathrm{Mn} / \mathrm{Cu}] \mathrm{Al}_{2} \mathrm{Si}_{2} \mathrm{O}_{7}(\mathrm{pH}$ 11) in Figure 3 .

In previous report, it was shown that tert-butyl mercaptan (TBM) dimerizes into di-fert-butyl disulfide (DBDS) over the surface of silica impregnated with $\mathrm{Mn}$ and $\mathrm{Cu}$, through
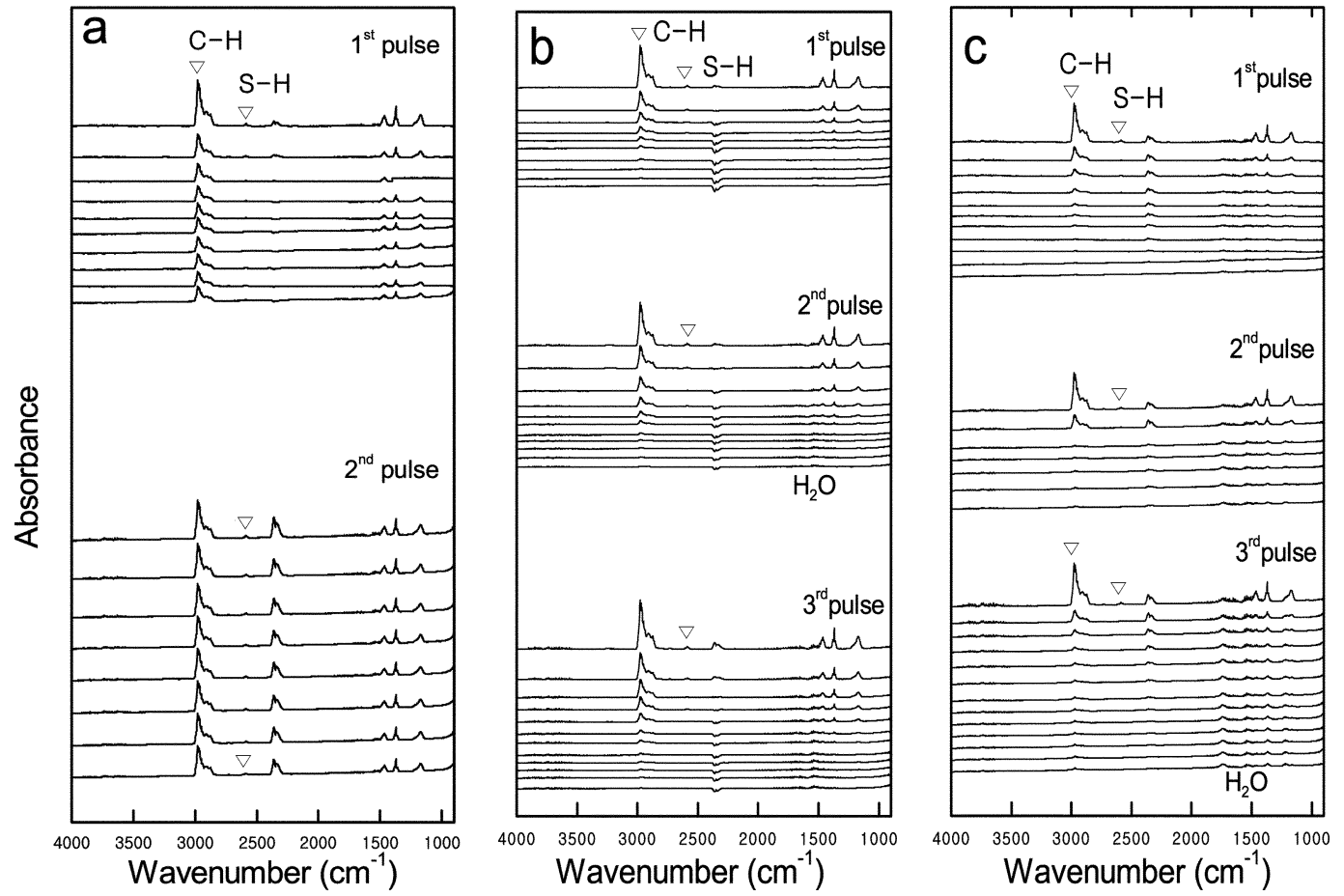

Figure 4. FIIR spectra taken for the consecutive pulses of TI3M, (a) over the blank support, aluminosilicate without [Mn/Cu] impregnated, (b) over the surface of $|\mathrm{Mn} / \mathrm{Cu}| \mathrm{Al}_{2} \mathrm{Si}_{2} \mathrm{O}_{7}$ (plI 7), and (c) over the surface of $|\mathrm{Mn} / \mathrm{Cu}| \mathrm{Al}_{2} \mathrm{Si}_{2} \mathrm{O}_{7}$ (plI $1 \mathrm{l}$ ). The lapse between consecutive spectra was $3 \mathrm{~min}$. Each cluster of the spectra represents measurements on one pulse of TBM. 
the following reaction. ${ }^{8}$

$$
2 \mathrm{C}_{4} \mathrm{H}_{4} \mathrm{SII}+\mathrm{I} / 2 \mathrm{O}_{2} \rightarrow \mathrm{C}_{4} \mathrm{II}_{9} \mathrm{SSC}_{4} \mathrm{II}_{9}+\mathrm{II}_{2} \mathrm{O} \Delta \mathrm{II}<0
$$

Without oxygen in the overhead gas, the reaction would not proceed. FT-IR spectra are very similar for both TBM and DBDS, execpt a few characteristic peaks by TBM. In disceming the reactant from the product, the best guidance is provided by the $\mathrm{S}-\mathrm{H}$ vibration of TBM at $2600 \mathrm{~cm}$ !. The C.-H vibration is also slightly shifted to $2990 \mathrm{~cm}$ ' in TBM. In order to verify the catalytic role of the impregnated transition metals over the surface of aluminosilicate, a blank support was prepared by heat-treating $\mathrm{Al}_{2} \mathrm{Si}_{2} \mathrm{O}_{7}(\mathrm{pH}$ 11) at $500^{\circ} \mathrm{C}$. without being impregnated. Over this blank support, a pulse of TMB was injected and in-situ monitored by FTIR, as shown in Figure 4a. Dimerization reaction of TBM was not oceuring over the surface of aluminosilicate, when it was not impregnated. Characteristic peaks of TBM at 2600 and $2990 \mathrm{~cm}$ ' are persistent over the time (see second pulse in figure 4a).

On the contrary, when TBM was injected over [Mn/ Cu] $\mathrm{Al}_{2} \mathrm{Si}_{2} \mathrm{O}_{7}(\mathrm{pH} \mathrm{11)}$, in Figure 4c, those two peaks started decreasing immediately. They disappeared in $10-15 \mathrm{~min}$, which indicates TBM was readily dimerized into DBDS over the surface of aluminosilicate impregnated with $\mathrm{Mn}$ and $\mathrm{Cu}$. Steady growth of water peaks around 1700 and $3700 \mathrm{~cm}{ }^{1}$ is also apparent, as the number of pulses adds up. Same observation was also made in Figure $4 \mathrm{~b}$ for $[\mathrm{Mn} /$ $\mathrm{Cu} \mathrm{Al}_{2} \mathrm{Si}_{2} \mathrm{O}_{7}(\mathrm{pH} 7)$. TBM peaks disappear in 10-15 min, and water peaks adds up with consecutive injections of TBM pulses. Therefore, both $[\mathrm{Mn} / \mathrm{Cu}] \mathrm{Al}_{2} \mathrm{Si}_{2} \mathrm{O}_{7}(\mathrm{pH} 7)$ and $[\mathrm{Mn} /$ $\mathrm{Cu}] \mathrm{Al}_{2} \mathrm{Si}_{2} \mathrm{O}_{7}(\mathrm{pH} 11)$ showed catalytic reactivity toward dimerization reaction of TBM, at least for a small quantity of it.

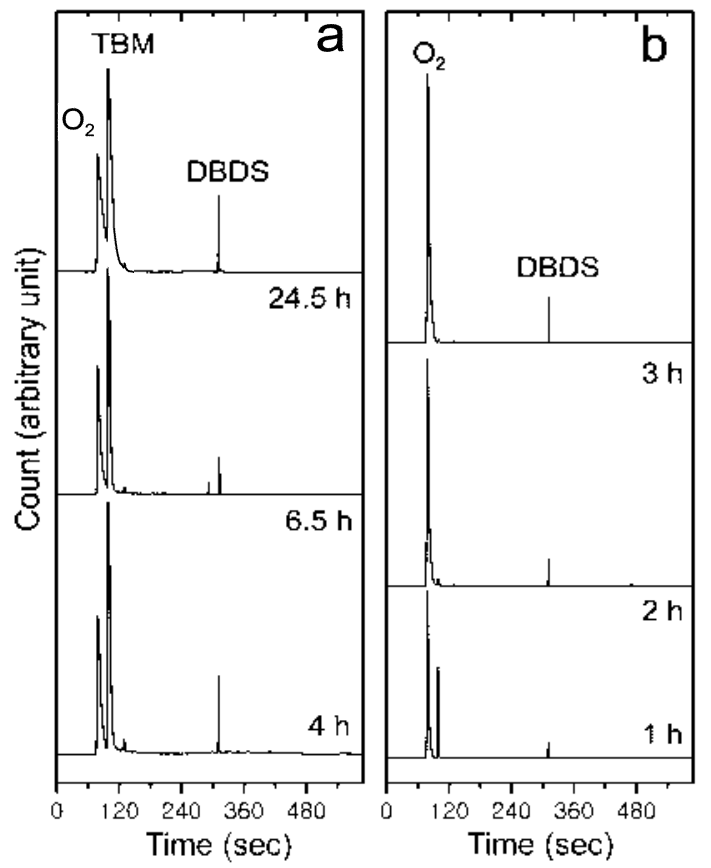

Figure 5. Gas chromalographs of the overhead gas oblained after designated time. The overhead gas was taken, (a) from $|\mathrm{Mn} / \mathrm{Cu}|-$ $\mathrm{Al}_{2} \mathrm{Si}_{2} \mathrm{O}_{7}(\mathrm{pH} 7)$, and (b) from $[\mathrm{Mn} / \mathrm{Cu}] \mathrm{Al}_{2} \mathrm{Si}_{2} \mathrm{O}_{7}(\mathrm{pH} \mathrm{Il})$.
Dimerization reaction on larger quantity of TBM over the surface of $[\mathrm{Mn} / \mathrm{Cu}] \mathrm{Al}_{2} \mathrm{Si}_{2} \mathrm{O}_{7}(\mathrm{pH} 7)$ and $[\mathrm{Mn} / \mathrm{Cu}] \mathrm{Al}_{2} \mathrm{Si}_{2} \mathrm{O}_{7}$ $(\mathrm{pH} 11)$ was monitored by GC/MS, shown in Figure 5 . The reaction of a larger quantity (40-fold) of TBM exhibits quite different outeome from the one seen by FT-IR above. The reaction over $\left[\mathrm{Mn}_{1} / \mathrm{Cu}\right] \mathrm{Al}_{2} \mathrm{Si}_{2} \mathrm{O}_{7}(\mathrm{pH} 7)$ was very slow that major portion of TBM was still registered as a large peak, in Figure 5a, even after a day. Fven though the BET surface area was larger (189.1 vs $\left.129.2 \mathrm{~m}^{2} / \mathrm{g}\right)$ than $[\mathrm{Mn} / \mathrm{Cu}] \mathrm{Al}_{2} \mathrm{Si}_{2} \mathrm{O}_{7}$ $(\mathrm{pH} 11),[\mathrm{Mn} / \mathrm{Cu}] \mathrm{Al}_{2} \mathrm{Si}_{2} \mathrm{O}_{7}(\mathrm{pH}$ 7) was not efficient in catalyzing dimerization at all. On the contrary, dimerization of TBM by $[\mathrm{Mn} / \mathrm{Cu}] \mathrm{Al}_{2} \mathrm{Si}_{2} \mathrm{O}_{7}(\mathrm{pH}$ 11) was almost complete in two hours (figure 5b). After three hours, a sensual test over an open vessel registered no stench from TBM at all.

Because vapor pressure of DBDS $\left(2.45 \mathrm{kPa}\right.$ at $\left.25^{\circ} \mathrm{C}\right)$ is much lower than that of TBM $\left(24,2 \mathrm{kPa}\right.$ at $\left.25^{\circ} \mathrm{C}\right)$, DBDS would preferably condense into the pores onee generated on the surface. In a previous GC-study on aerosil ${ }^{k}$ impregnated with $\mathrm{Mn}$ and $\mathrm{Cu}^{8}$ an elemental analysis showed that considerable amount of DBDS was staying on the surface. As surface was saturated by physisorbed DBDS, dimerization of TBM was largely suppressed, presumably because reactive sites could not be reached by incoming TBM.

The strikingly different outcome of the GC-MS measurements above suggests that the morphology of a surface is a major reason to influenec adsorption and desorption proeesses on the surface of solids. The difference in the pore shapes in Figure 4 provides a clue to this observation. The volume of DBDS molecule is about twice larger than TBM. Therefore, TBM casily enters into so called "ink-bottled" pores on the surface of $[\mathrm{Mn} / \mathrm{Cu}] \mathrm{Al}_{2} \mathrm{Si}_{2} \mathrm{O}_{7}(\mathrm{pH} 7)$. Tut as TBM dimerizes into much larger DBDS in the "bottle", out bound flux of the product gas is largely blocked. Unless DBDS is flushed out of the "bottle", the equilibrium of the adsorption and desorption of DBDS would shift toward adsorption inside these "bottled" pores. Thereby, acess to reactive sites by incoming TBM is namely denied in [Mn/ $\mathrm{Cu}] \mathrm{Al}_{2} \mathrm{Si}_{2} \mathrm{O}_{7}(\mathrm{pH} 7)$. On the contrary, cylindrical shape of the pores in $[\mathrm{Mn} / \mathrm{Cu}] \mathrm{Al}_{2} \mathrm{Si}_{2} \mathrm{O}_{7}(\mathrm{pH} 11)$ with a range of different sizes, apparently gave better chance to release DBDS, thereby, readily exposing reactive sites to incoming TBM. Moreover, the surface of $[\mathrm{Mn} / \mathrm{Cu}] \mathrm{Al}_{2} \mathrm{Si}_{2} \mathrm{O}_{7}(\mathrm{pH} 7)$ contains more micropores, as can be seen in Table 1 , than in [Mn/ $\mathrm{Cu}] \mathrm{Al}_{2} \mathrm{Si}_{2} \mathrm{O}_{7}(\mathrm{pH} 11)$. Therefore, DBDS would adhere more adamantly on the surface of $[\mathrm{Mn} / \mathrm{Cu}] \mathrm{Al}_{2} \mathrm{Si}_{2} \mathrm{O}_{7}(\mathrm{pH} 7)$, blocking the reactive sites.

Similar observation was made in previous study on silica aerosil $^{\mathrm{K}}$ impregnated with $\mathrm{Mn}$ and $\mathrm{Cu}$, that turnover kept decreasing as large amount of TBM was passed over the destructive adsorbent. These observations indicate that active sites are poisoned by product of the very reaction they catalized. Even though the active sites can be revived by heating, via reverse reaction below, such necessity will tarnish the commercial value of the destructive adsorbent.

$$
\mathrm{C}_{4} \mathrm{I}_{4} \mathrm{SSC}_{4} \mathrm{Il}_{9}+\mathrm{II}_{2} \mathrm{O} \rightarrow 2 \mathrm{C}_{4} \mathrm{I}_{9} \mathrm{SH}+\mathrm{I}_{2} \mathrm{O}_{2} \Delta \mathrm{II}>0
$$

Therefore, it would be better to adjust surface morphology 
so that the adsorption of reactant and release of product would be well balanced.

\section{Conclusions}

Amorphous aluminosilicates in large surface area were prepared by precipitation of aluminosilicate sol. By adjusting $\mathrm{pH}$ during the precipitation, aluminosilicates in different morphologies could be obtained. The aluminosilicate prepared at $\mathrm{pH}=7$ contained so called "ink-bottled" pores, while the one obtained at $\mathrm{pH}=11$ had cylindrical ones. For both samples, major fraction of total surface area was from micropores.

These aluminosilictes in the different surface morphologies were used as supports for the destructive adsorbents, whose surface was impregnated with $\mathrm{Mn}$ and $\mathrm{Cu}$. During the process of the impregnation and subsequent heat-treatment, the shape of the pore was preserved, while a large fraction of micropores was eliminated, which accompanied the loss of BET surface area.

When impregnated with $\mathrm{Mn}$ and $\mathrm{Cu}$, the surface of amorphous aluminosilicates turned highly reactive toward dimerization of TBM, catalytically tuming it into DBDS. The rate of dimerization was strongly dependent on the surface morphology. When the surface had high population of "ink-bottled" mesopores, the catalytic reactivity of the surface was largely spoiled, if once dimerization got started. It is suggested that access by incoming TBM over the reactive sites were blocked as DBDS got trapped in the pores and adhered on the reactive sites. Apparently, poisoning was not that severe when the surface had cylindrically shaped mesopores in a wide range of the size.

\section{References}

I. Yoshimoto, M.; Nakatsuji, T.; Yoshida, K. Jpn, Kokai Tokkjo Koho JP 04,277,014, 1992.

2. Okuda, Y. Jpn. Kokai Tokko Koho JP 06, 122,519, 1994.

3. Becker, O.; Kolz. S.; Hager, H. Eur. Pat. Appl. EP 633065, 1995.

4. Cha, Y. S.; Cadwallader, K. R. J. Food Sci. 1995, 60( I), 19.

5. Martin-Lagos, R. A.; Olea Serrano, M. F.; Ruiz Lopez, M. D. Food Chem. 1995, 53, 91 .

6. Odorization II, Wilson, G. G., Attari, A. A., Eds.; Instiute of Gas Technology: Chicago, Illinois, USA, 1998.

7. Park, S. H.; Park, D. G.; Kweon, H. J.; Nam, S. S.; Kim, S. B.; Lee, Y. B.; Choe, K. H. Bull. Korean Chem. Soc 1999, 20(6), 639.

8. Park, D. G.; Park, S. H.; Lee, S. J. Bull. Korean Chem. Soc. 2000 , $21(7), 715$.

9. Lowell, S.; Shields, J. E. Powder Surface Area and Porosity; $3^{\text {th }}$ Ed.; Chapman \& Hall: London, UK, 1991; p 11.

10. Gregg. S. J.; Sing. K. S. W. Adsorption, Strrface Area and Porosity; $2^{\text {nd }} \mathrm{Ed}$.; Academic press: Londodn, UK, 1982; p Ill.

11. Brinker, C. J.; Scherer, G. W. Sol-Gel Science: The Physics and Chemistry of Sol-Gel Processing; Academic press: San Diego, USA, 1990; pp 97-107.

12. Kim, H. J.; Kang, J.; Park, D. G.; Kweon. H. J.; Klabunde, K. J. Butl. Korean Chem. Soc. 1997, 18(8), 831. 